\title{
Prediction of Reservoir Temperature for the Tianjin Geothermal Field, Bohai Bay Basin, China
}

\author{
Ying Pei \\ Xi'an Center of Geological Survey, CGS \\ Xi'an, China \\ e-mail:peiyingcsgs@163.com
}

\begin{abstract}
Reservoir temperature is a key parameter for genesis analysis, potential evaluation and research of waterrock interactions of geothermal systems. It is necessary to identify the suitable geothermometer for a certain geothermal field for better characterization of the geo-temperature field. In this paper we attempt to determine the most suitable geothermometer applied to the Tianjin Geothermal field, Bohai Bay Basin, China by a systematic sampling and analysis of the water samples collected from five sandstone and carbonate geothermal reservoirs during year 2009 to 2010. Results show that most of the water samples are not in full equilibrium with the reservoir rock indicated by the Giggenbach triangular diagram and thus cation geothermometers cannot be applied, while chalcedony geothermometer instead of the other quartz varieties is found to be the most suitable one based on saturation index calculation. The temperature predicted are $\pm 5^{\circ} \mathrm{C}$ compared to that of the well head temperature, and the reservoir temperature of the Tianjin geothermal filed is estimated to be less than $100^{\circ} \mathrm{C}$, falling into the low to medium temperature range.
\end{abstract}

\section{Keywords-geothermometer; reservoir temperature; tianjin}

\section{INTRODUCTION}

Reservoir temperature is a key parameter for classifycation, genesis analysis, potential evaluation of geothermal resources in geothermal exploration and development. In the cases when geothermal fields have surface manifestations or boreholes are not deep enough to reveal the reservoirs, fluid geothermometer can play as a cost-effective tool in the prediction of reservoir temperature. It uses the relationship of temperature and solute or gas content in geothermal fluid to predict reservoir temperature. This is based on the assumption that thermodynamic equilibrium is achieved between mineral and fluid or different fluids in the reservoir, which can be maintained during ascending to the surface irrespective of cooling. Research of geothermometer started in the 1950s, nowadays geothermometers based on thermodynamic theory have been fully developed and widely applied. The most widely used ones include cation, silica, gas, isotope and chemical thermodynamic geothermometer. However, in some cases, there can be large discrepancies between reservoir temperature estimated by geothermometers and the real value, thus it is necessary to evaluate the equilibrium conditions of the water-rock interactions to choose the most applicable geothermometer.
The Tianjin geothermal field is characterized of excellent occurrence condition, great potential and a long development history, it is the most typical and thoroughly studied geothermal field in North China. There are both sandstone and carbonate reservoirs in the geothermal field, with abundance water chemistry and temperature logging data, providing a good foundation for testing of the applicability of geothermometers in low to medium temperature geothermal fields. For this purpose, we take the Tianjin geothermal fields as a case, to predict the reservoir temperature and evaluate the applicability of two most commonly used geothermometers, i.e. the cation and silica thermometers. The conclusions have important practical significance for the same type geothermal fields in North China.

\section{MATERIALS AND METHEODS}

\section{A. Study area}

Tianjin geothermal field, with an area of $11,900 \mathrm{~km}^{2}$ is tectonically located at the northeastern part of the Baohai Bay Basin (BBB), which is developed on the Archean basement of the North China Craton (Li, 1986). The Achean system is composed of gneiss, granulite and quartzite, and is overlain by a Middle-Upper Proterozoic shallow water marine succession. The Phanerozoic system in the region is composed of Cambrian-Middle Ordovician shallow-marine carbonates, Upper Carboniferous-Lower Permian carbonates and coal-bearing clastics, Upper Permian-Triassic red beds and conglomerates, Jurassic coal-bearing clastics and continental volcano-sedimentary units which overlie older units unconformably (Davis et al., 2001), Cretaceous terrestrial volcanic rocks, volcaniclastic and clastic rocks, Eocene - Oligocene inland lacustrine sandstone and clay, Neogene fluvial and inland lacustrine sandstone, clay and Quaternary alluvial sandstone, clay and some marine deposits. The Quaternary has a thickness of 250-550 m, and stretches across the whole basin, forming a regional caprock for the underlying reservoirs. There are in total five main geothermal reservoirs in the Tianjin geothermal filed, which can be summarized from the top to the bottom as follows: (i) The Neogene Minghuazhenreservoir (Nm), with a thickness of 230-1300 m, mainly comprises mudstones and interlayered with fine sandstone and covers the whole basin. (ii) The Neogene Guantao reservoir $(\mathrm{Ng})$, with a thickness of 126-1520 m, comprises silty and fine sandstones interlayered with mudstone in the upper and pebbled sandstone 
inter-layered with mudstone in the lower, and covers the whole basin except for some areas in the structural high of the Cangxian Uplift. (iii) The Cambrian and Ordovician Reserviors, which are located mainly in the Cangxian Uplift. The Cambrian reservoir has a thickness of 50-120 m and a buried depth of 1300-1800 m, while the Ordovician reserveoir has a thickness of 450-750 m and a buried depth of 1000-2000 m (Lin, 2006). (iv) The Precambrian reservoir, with a thicknesses of $2550-5200 \mathrm{~m}$ and a buried depth of 910-3200 m, mainly comprises limestone and dolostone (Zhai, 1997).

\section{B. Sampling and analyses}

Altogether 30 chemical data on water samples were considered (Figure 1), among which 13 samples were collected from the geothermal production wells during two sampling campaigns in December, 2009 and March, 2010, respectively. Analyses of water were conducted at the Analytical Laboratory, Beijing Research Institute of

Uranium Geology, where anions of $\mathrm{F}^{-}, \mathrm{Cl}^{-}, \mathrm{SO}_{4}{ }^{2-}, \mathrm{NO}_{3}{ }^{-}$ were measured with a DIONEX-500 ion chromatograph, cations with an OPTIMA2X00/1500 ICP-OES and alkalinity using an automatic titrator (785DMPTM). The other 17 samples were collected from thermal water exploration wells during 2004 to 2007 and the analyses were conducted at Tianjin Geology \& Mineral Resources Experiment Center, where anions were measured with a DIONEX-ICS-1500 ion chromatograph, cations with an IRIS Intrepid II ICP-OES and alkalinity by titration. The methods for cation measurements were those of the National Analysis Standard DZ/T0064.28-93 and for anions DZ/T0064.51-93, while the same standard reference water samples distributed by the National Institute of Metrology, China were used. The analytical precision was $3 \%$ of concentration based on reproducibility of samples and standards and the detection limit was $0.1 \mathrm{mg} / \mathrm{L}$. The charge balance error for the samples ranges from $-5 \%$ to $5 \%$ (Table I).

\section{RESUlTS AND DisCUSSION}

Cation and silica goethermometers (Arnórsson, 2000) are used to estimate the reservoir temperature (Table II). The results show significant differences in the temperatures estimated for various cation goethermometers, and most results are far from the well head temperature, ether estimated too low or too high. It deviates from the monitoring experience that well head temperatures only have a minor uncertainty with respect to the reservoir temperatures, of ca. $1{ }^{\circ} \mathrm{C} / \mathrm{km}$ (Yang, et al., 2013). This may be resulted from disequilibrium of water-rock interactions, which can be inferred from the Giggenbach triangular diagram (Figure 2). It shows that almost all water samples fall in the regions of partially equilibrated and mixed waters or immature waters, which indicates that cation geothermometers cannot be applied in the Tianjin geothermal field.

Two quartz goethermometers show estimated temperatures $27-37^{\circ} \mathrm{C}$ higher than the well head temperatures, while chalcedony goethermometer show the best estimation of the reservoir temperatures, with a discrepancy of $\pm 5^{\circ} \mathrm{C}$, except for well 16, which may be caused by mixing of the
Ordovician reservoir and other geothermal reservoirs (Yang et al., 2013).

In order to determine the controlling phase of the silica species in the water-rock interaction of the reservoirs, saturation index $(\log \mathrm{Q} / \mathrm{K})$ of silica species for the Tianjin geothermal water are calculated by the thermodynamic modeling code Solveq (Figure 3). It shows that among the five species considered, water samples is supersaturated with quartz and undersaturated with amorphous silica and $\beta$ cristobalite. Most water samples are also undersaturated with $\alpha$-cristobalite, except for well 3,4 and 7. Chalcedony is the only species with the saturation index around zero, indicating most close to equilibrium with the reservoir rock. Thus it is chalcedony that controls dissolved silica in the reservoir, which is usually the case when reservoir temperature bellows $120-180^{\circ} \mathrm{C}$ (Fournier, 1989).

According to the well head temperature and that predicted by the chalcedony geothermometer, it is inferred that the reservoir temperatures within $3000 \mathrm{~m}$ depth are less than $100{ }^{\circ} \mathrm{C}$ (taken into account the heat loss during water ascent to the well head), falling into the low to medium temperature range.

\section{CONCLUSIONS}

Waters samples from various reservoirs in the Tianjin geothermal filed fall into the region of partially equilibrium or immature waters, indicating that cation geothermometers are not applicable, and are proved by the estimated temperature which are far from the well head temperature.

Quartz goethermometers show estimated temperatures $27-37^{\circ} \mathrm{C}$ higher than the well head temperatures, while chalcedony goethermometer show the best estimation of the reservoir temperatures, with a discrepancy of $\pm 5^{\circ} \mathrm{C}$.

Saturation index of five varieties of silica species for the thermal waters are calculated and the results show that it is chalcedony other than quartz, $\alpha$-cristobalite, $\beta$-cristobalite and amorphous silica which controls dissolved silica in the reservoir and can be used as a good geothermometer applicable to the Tianjin geothermal filed.

\section{REFERENCES}

[1] D.S. Li, "The compounded geological characteristics of the Bohai Bay Basin," China Petrol. vol.7, pp. 20-31, 1986.

[2] G.A. Davis, Y. Zheng, C. Wang, B.J. Darby, C. Zhang, and G. Gehrels, "Mesozoic tectonic evolution of the Yanshan fold and thrust belt, with emphasis on Hebei and Liaoning Provinces, northern China," Geol. Soc. Am. Mem. Vol.194, pp.171-197, 2001.

[3] L. Lin, "Sustainable development and utilization of thermal groundwater resources in the geothermal reservoir of the Wumishan Group in Tianjin," Ph.D. Dissertation, China Univ. Geosciences, Beijing, 2006.

[4] G.M. Zhai (Ed.), Petroleum geology of China. Beijing: Petroleum Industry Press, 1997.

[5] S. Arnórsson (Ed.), "Isotopic and chemical techniques in geothermal exploration, development and use," Vienna: International atomic energy agency, 2000.

[6] F.T. Yang, Z.H. Pang, L. Lin, Z. Jia, F.N. Zhang, Z.F. Duan and Z.H. Zong, "Hydrogeochemical and isotopic evidence for transformational flow in a sedimentary basin: Implications for $\mathrm{CO}_{2}$ storage," Applied Geochemistry, vol. 30, 2013, pp. 4-15. 
[7] R.O. Fournier, "Solubility of silica in hydrothermal solutions: practical applications," United Nations Geothermal Training Programme, Reykjavik, Iceland, Report No. 10, pp. 21-39, 1989.

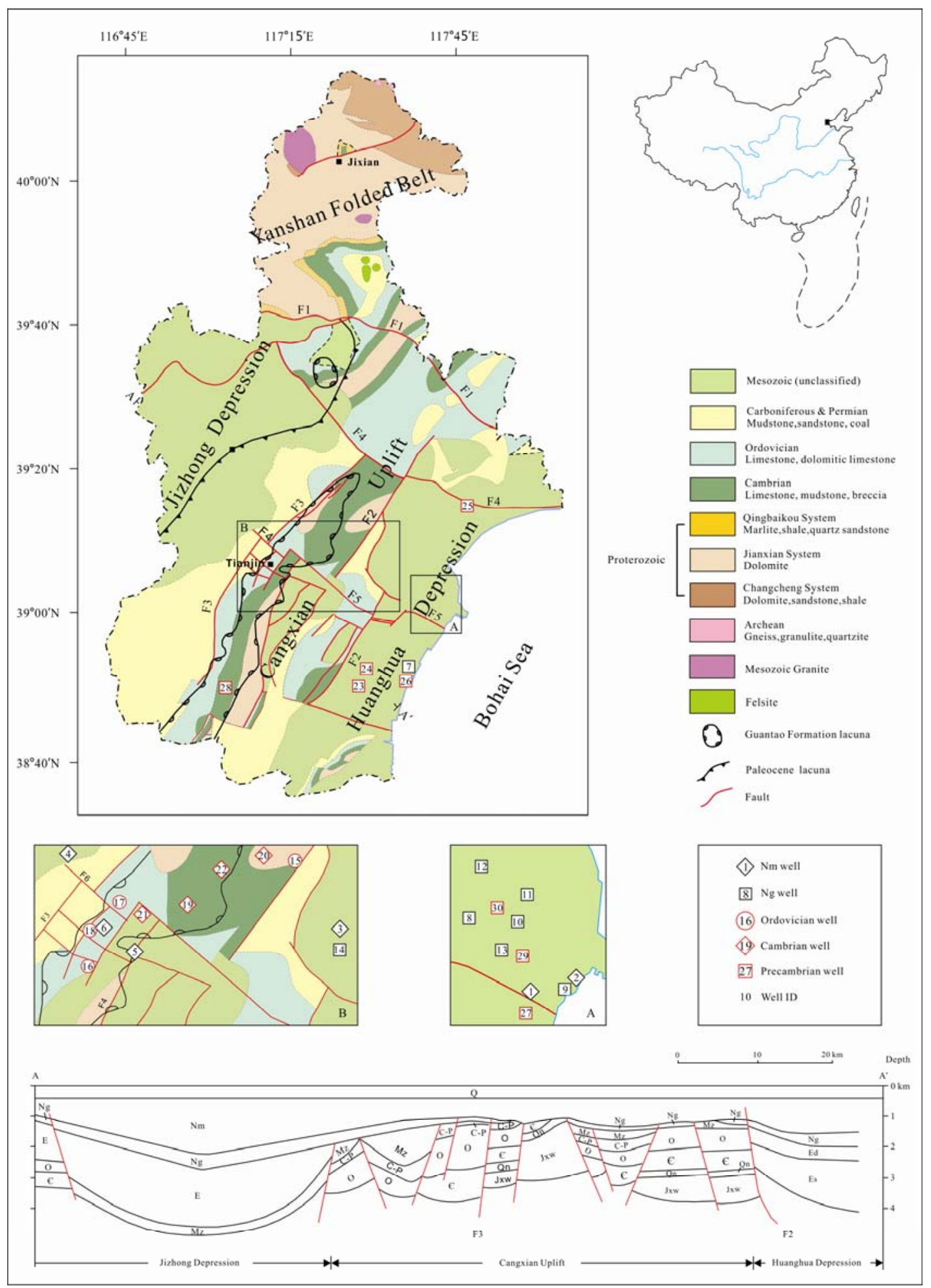

Figure 1. Location of the study area and sampling site. 
TABLE I. WATER CHEMISTRY OF THE TIANJIN GEOTHERMAL FIELD（MG/L）

\begin{tabular}{|c|c|c|c|c|c|c|c|c|c|c|c|c|c|c|c|}
\hline Wells & Date & Reservoir & Depth(m) & pH & $\mathrm{t}\left({ }^{\circ} \mathrm{C}\right)$ & $\mathrm{Na}^{+}$ & $\mathbf{K}^{+}$ & $\mathrm{Mg}^{2+}$ & $\mathrm{Ca}^{2+}$ & $\mathrm{Cl}^{-}$ & $\mathrm{SO}_{4}{ }^{2-}$ & $\mathrm{HCO}_{3}{ }^{-}$ & $\mathbf{F}^{-}$ & $\mathrm{SiO}_{2}$ & TDS \\
\hline 1 & 23-Dec-09 & $\mathrm{Nm}$ & 1906 & 8.2 & 40 & 309.0 & 4.5 & 0.8 & 5.1 & 52.1 & 53.4 & 595.8 & 3.2 & 22.0 & 748.0 \\
\hline 2 & 23-Dec-09 & $\mathrm{Nm}$ & 1913 & 8.4 & 46 & 293.0 & 4.1 & 0.7 & 4.6 & 21.2 & 28.2 & 668.6 & 4.3 & 25.9 & 716.3 \\
\hline 3 & 23-Dec-09 & $\mathrm{Nm}$ & 1959 & 8.6 & 43 & 300.0 & 11.8 & 2.0 & 10.0 & 85.1 & 73.8 & 590.3 & 4.0 & 29.8 & 811.7 \\
\hline 4 & 3-Dec-04 & $\mathrm{Nm}$ & 1286 & 8.4 & 49 & 605.5 & 3.6 & 3.0 & 9.0 & 698.4 & 12.0 & 457.6 & 5.2 & 27.2 & 1594.0 \\
\hline 5 & 9-Jan-07 & $\mathrm{Nm}$ & 2010 & 8.6 & 42 & 247.8 & 1.4 & 0.5 & 3.2 & 60.3 & 17.1 & 497.3 & 4.9 & 25.6 & 620.0 \\
\hline 6 & 1-Dec-06 & $\mathrm{Nm}$ & 1293 & 7.9 & 44 & 968.3 & 10.1 & 28.6 & 173.5 & 531.8 & 1824.9 & 109.8 & 1.6 & 25.6 & 3636.0 \\
\hline 7 & 4-Dec-06 & $\mathrm{Ng}$ & 2222 & 8.4 & 72 & 544 & 4 & 0.5 & 10.6 & 388.2 & 297 & 433.2 & 7.9 & 45.0 & 2222.0 \\
\hline 8 & 23-Dec-09 & $\mathrm{Ng}$ & 2049 & 7.4 & 63 & 509.0 & 10.5 & 1.4 & 14.7 & 277.4 & 184.7 & 640.6 & 4.5 & 37.1 & 1360.0 \\
\hline 9 & 23-Dec-09 & $\mathrm{Ng}$ & 1994 & 7.6 & 70 & 519.0 & 11.5 & 1.1 & 10.8 & 272.7 & 172.0 & 670.1 & 4.9 & 48.0 & 1375.1 \\
\hline 10 & 23-Dec-09 & $\mathrm{Ng}$ & 2025 & 7.6 & 66 & 496.0 & 9.8 & 0.9 & 10.9 & 258.0 & 175.3 & 635.2 & 6.9 & 39.7 & 1316.0 \\
\hline 11 & 23-Dec-09 & $\mathrm{Ng}$ & 2070 & 7.7 & 60 & 477.0 & 10.0 & 0.9 & 11.6 & 225.5 & 163.2 & 644.7 & 5.3 & 39.8 & 1255.7 \\
\hline 12 & 23-Dec-09 & $\mathrm{Ng}$ & 2040 & 7.7 & 60 & 491.0 & 10.4 & 1.3 & 12.9 & 284.6 & 196.9 & 620.2 & 6.4 & 38.6 & 1353.0 \\
\hline 13 & 29-Nov-05 & $\mathrm{Ng}$ & 2025 & 8.5 & 65 & 551 & 5.4 & 2.4 & 11 & 354.5 & 254.6 & 643.1 & 8.3 & 41.8 & 1504.0 \\
\hline 14 & 23-Dec-09 & $\mathrm{Ng}$ & - & 7.7 & 54 & 465.0 & 17.7 & 3.1 & 18.8 & 258.8 & 173.7 & 611.2 & 6.2 & 33.0 & 1283.0 \\
\hline 15 & 12-Nov-06 & Ordovician & 2318 & 7.7 & 70 & 466.3 & 51.6 & 9.1 & 40.0 & 386.4 & 257.5 & 497.3 & 8.5 & 44.5 & 1504.0 \\
\hline 16 & 6-Dec-06 & Ordovician & 1544 & 7.4 & 57 & 839.8 & 45.0 & 94.2 & 482.5 & 875.6 & 2044.0 & 192.2 & 4.0 & 30.2 & 4507.4 \\
\hline 17 & 12-Mar-10 & Ordovician & 1312 & 7.4 & 65 & 487.0 & 96.0 & 9.8 & 69.0 & 333.7 & 260.2 & 567.7 & 8.6 & 48.5 & 1549.4 \\
\hline 18 & 5-Dec-06 & Ordovician & 1516 & 7.5 & 43 & 819.4 & 40.2 & 98.6 & 476.5 & 822.4 & 2027.0 & 164.8 & 4.0 & 27.6 & 4394.0 \\
\hline 19 & 8-Dec-06 & Cambrian & 2468 & 7.5 & 82 & 482.3 & 73 & 12 & 30.6 & 428.9 & 320.4 & 393.6 & 10.8 & 65.2 & 1609.0 \\
\hline 20 & 17-Nov-05 & Cambrian & 1727 & 7.9 & 96 & 420.9 & 95.0 & 10.3 & 37.1 & 375.8 & 312.2 & 414.9 & 9.0 & 74.8 & 1533.6 \\
\hline 21 & 12-Mar-10 & Cambrian & 2010 & 7.2 & 84 & 471.0 & 114.0 & 12.3 & 40.0 & 388.6 & 275.5 & 456.6 & 9.8 & 66.5 & 1539.4 \\
\hline 22 & 13-Dec-04 & Cambrian & 1492 & 7.7 & 78 & 436.9 & 70.3 & 7.9 & 51.1 & 372.2 & 331.4 & 433.2 & 7.9 & 55.0 & 1541.4 \\
\hline 23 & 8-Dec-06 & Precambrian & 2450 & 7.8 & 86 & 493.1 & 75.2 & 12.4 & 30.2 & 452.0 & 329.5 & 378.3 & 11.4 & 65.2 & 1646.8 \\
\hline 24 & 8-Dec-06 & Precambrian & 2949 & 7.4 & 86 & 435.8 & 83.4 & 12.4 & 43.3 & 375.8 & 294.3 & 445.4 & 11.4 & 67.7 & 1535.4 \\
\hline 25 & 16-Dec-04 & Precambrian & 2058 & 7.8 & 90 & 456.3 & 77.0 & 10.9 & 37.1 & 434.3 & 339.1 & 375.3 & 10.6 & 64.5 & 1606.8 \\
\hline 26 & 9-Dec-04 & Precambrian & 3000 & 7.7 & 86 & 454.0 & 76.0 & 12.2 & 37.1 & 390.0 & 299.7 & 418.0 & 11.2 & 65.0 & 1543.0 \\
\hline 27 & 1-Dec-04 & Precambrian & 2443 & 7.7 & 86 & 470.2 & 68.8 & 12.2 & 33.1 & 428.9 & 333.3 & 375.3 & 11.6 & 63.5 & 1597.6 \\
\hline 28 & 16-Dec-04 & Precambrian & 2611 & 7.7 & 84 & 461.9 & 75.4 & 13.4 & 33.1 & 443.1 & 339.1 & 372.2 & 10.6 & 63.0 & 1615.1 \\
\hline 29 & 1-Dec-04 & Precambrian & 2492 & 8.4 & 86 & 470.8 & 73.8 & 11.6 & 35.1 & 441.4 & 336.2 & 378.3 & 12.0 & 66.0 & 1624.0 \\
\hline 30 & 1-Dec-04 & Precambrian & 2481 & 7.7 & 86 & 481.5 & 75.0 & 13.4 & 31.1 & 444.9 & 309.3 & 375.3 & 10.6 & 63.5 & 1606.4 \\
\hline
\end{tabular}


TABLE II. TEMPERATURE EQUATIONS FOR CATION AND SILICA GEOTHERMOMETERS (CONCENTRATION CATIONS IN MOL/KG AND SILICA IN $\mathrm{MG} / \mathrm{KG})$

\begin{tabular}{|c|c|c|c|}
\hline Geothermometer & Equation $\left(t\right.$ in ${ }^{\circ} \mathrm{C}$ ) & Range $\left({ }^{\circ} \mathrm{C}\right)$ & Source \\
\hline $\mathrm{Na}-\mathrm{K}$ & $\frac{933}{0.993+\log (\mathrm{Na} / \mathrm{K})}-273.15$ & $25-250$ & Arnórsson et al. (1983) \\
\hline $\mathrm{K}-\mathrm{Mg}$ & $\frac{2330}{7.35+\log \left(\mathrm{K}^{2} / \mathrm{Mg}\right)}-273.15$ & $0-350$ & Fournier (1991) \\
\hline $\mathrm{Na}-\mathrm{K}-\mathrm{Mg}$ & $\frac{4410}{114.00-\log \left(\mathrm{K}^{2} / \mathrm{Mg}\right)}-273.15$ & $0-350$ & Giggenbach (1988) \\
\hline $\mathrm{Na}-\mathrm{Ca}$ & $\frac{1096.7}{3.08-\log \left(\mathrm{Na} / \mathrm{Ca}^{0.5}\right)}-273.15$ & $0-350$ & Tonani (1980) \\
\hline $\mathrm{K}-\mathrm{Ca}$ & $\frac{1930}{3.861-\log \left(\mathrm{K} / \mathrm{Ca}^{0.5}\right)}-273.15$ & $0-350$ & Tonani (1980) \\
\hline Chalcedony & $\frac{1032}{4.69-\operatorname{logS}}-273.15$ & $0-250$ & Fournier (1977) \\
\hline Quartz & $\frac{1309}{5.19-\operatorname{logS}}-273.15$ & $25-250$ & Fournier (1977) \\
\hline Quartz* & $\frac{1522}{5.75-\log S}-273.15$ & $25-250$ & Fournier (1977) \\
\hline
\end{tabular}

* Silica concentration in water initially in equilibrium with quartz after adiabatic boiling to $100^{\circ} \mathrm{C}$.

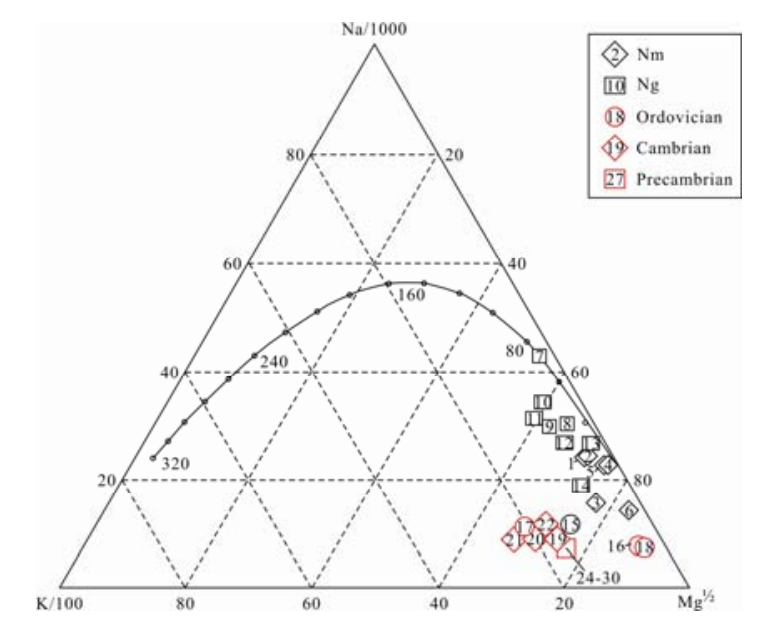

Figure 2. Giggenbach triangular diagram for water samples from the Tianjin geothermal filed. 